\title{
DIE MOONTLIKHEID VAN VERPLIGTE MIV-TOETSING VIR SEKSWERKERS IN SUID-AFRIKA NA DEKRIMINALISERING
}

\author{
Rinda Botha \\ BJuris LLB LLM LLD \\ Senior dosent \\ Departement Straf- en Geneeskundige Reg \\ Universiteit van die Vrystaat \\ Johann Pienaar \\ BCom (Regte) \\ Universiteit van die Vrystaat
}

\section{SUMMARY}

At present, the possibility of the decriminalization of the sex trade enjoys serious consideration by the South African Law Commission. With the spread of HIV still a big concern in South Africa, this article investigates the constitutionality of compelling sex workers to undergo HIV-testing, should the sex trade be decriminalized. This is done by examining existing South African case law and legislation in the field of compulsory HIV-testing. The South African position is followed by a comparative study with Nevada (USA) and Victoria (Australia) where sex work has been practised as a legal occupation for several years. Authors are of the opinion that the legislation of both these countries set a good example for South Africa in combating the spread of HIV through the sex industry, once decriminalized.

\section{INLEIDING}

Prostitusie is tans ' $n$ misdaad in Suid-Afrika en word ingevolge artikel 20(1)(1A) van die Wet op Seksuele Misdrywe 23 van 1957 as volg omskryf:

"lemand, 18 jaar of ouer, wat -

(a) ontug of 'n onsedelike daad met 'n ander persoon teen vergoeding pleeg; of

(b) in die openbaar 'n onsedelike daad met 'n ander persoon pleeg, is skuldig aan 'n misdryf."

Alhoewel prostitusie steeds 'n misdryf uitmaak, word die moontlikheid van dekriminalisering tans ernstig oorweeg en is die besprekingsdokument oor 
die moontlike dekriminalisering van prostitusie reeds vir kommentaar uitgereik. ${ }^{1}$

Terwyl die dekriminalisering van die seksbedryf aandag geniet, blyk die land se MIV-statistiek egter uiters kommerwekkend te wees. In Suid-Afrika alleen is ongeveer 5.6 miljoen mense in 2008 MIV-positief gediagnoseer. ${ }^{2}$ Verder raam die Internasionale Arbeidsorganisasie dat die Suid-Afrikaanse arbeidsmag teen 2020 ongeveer $17 \%$ kleiner sal wees as in die jaar 2000, juis as gevolg van MIV. ${ }^{3}$

Die heteroseksuele manier van oordrag word tans as grootste bron van MIV-oordrag beskou. ${ }^{4}$ Daar is dus geen twyfel oor die effek wat die moontlike dekriminalisering van die seksbedryf op die land se MIV-syfers kan toon nie. MIV-infektering is 'n integrale risiko verbonde aan sekswerkers se daaglikse werksaamhede.

Volgens Peltzer et $a^{f}$ het 'n opname in 1996 onder 145 vroulike sekswerkers by vragmotor-oornagstaanplekke in die Natalse Middelland daarop gedui dat $50,3 \%$ van die sekswerkers MIV-positief was. Wat vragmotor-oornagstaanplekke langs die Tanzanië-Zambiese hoofweg betref, was die voorkoms van MIV onder sekswerkers 50\%. In Johannesburg het 'n opname deur Rees et $\mathrm{al}^{\vec{l}}$ in die jaar 2000 getoon dat $45 \%$ van die sekswerkers MIV-positief was. Verder het Mzaidume et al in die jaar 2000 beweer dat sewe uit elke tien sekswerkers in Suid-Afrika MIV-positief is.

In die lig van bogenoemde kommerwekkende statistiek is Suid-Afrika genoop om vroegtydig aan voorkomingsmaatreëls aandag te gee, sou dekriminalisering inderdaad plaasvind. Een van die voorkomingsmaatreëls wat moontlik ingestel kan word, is die beheer of kontrole oor verpligte

South African Law Reform Commission Discussion Paper on Adult Prostitution 2009.

http://www.metam.co.za/documents_v2/File/RedRibbon_2009/Provincial\%20HIV\%20 and\% 20AIDS\%20statistics\%20for\%202008.pdf (nageslaan op 2010-01-21).

Joy Mining Machinery v NUMSA 20024 BLLR 372 (LC) 374.

4 Sien Varga "Coping with HIV/AIDS in Durban's Commercial Sex Industry" 2001 13(3) AIDS CARE 352: "The majority of infections are heterosexual and among young adults". Sien verder Slonim-Nevo, Mukuka en Tembo "AIDS-related Knowledge, Attitudes and Behaviour Among Urban Youths in Zambia" 2001 44(4) International Social Work 487: "Aids in subSaharan Africa is primarily a heterosexual problem". Asook Dane "Disclosure. The Voices of Thai Women Living with HIV/AIDS" 2002 45(2) International Social Work 185: "Among heterosexual men, unprotected sex with female commercial sex workers is the primary factor contributing to HIV transmission."

5 Peltzer, Seoka en Raphala "Characteristics of Female Sex Workers and their HIV/AIDS/STI Knowledge, Attitudes and Behaviour in Semi-urban Areas in South Africa" 2004 27(1) Curationes 4.

6 Outwater, Nkya, Lyamuya, Lwihula, Green, Hogle, Hassig en Dallabetta "Health Care Seeking Behaviour for Sexually Transmitted Diseases Among Commercial Sex Workers in Morogoro, Tanzania" 2001 3(1) Culture, Health \& Sexuality 20.

7 Rees, Beksinska, Dickson-Tetteh, Ballard en Htun "Commercial Sex Workers in Johannesburg: Risk Behaviour and HIV Status" 200096 South African Journal of Science 284.

8 Mzaidume, Campbell en Williams "Community-led HIV Prevention by Southern African Sex Workers" 20003 Research for Sex Work 23. 
kondoom-gebruik deur sekswerkers. ${ }^{9}$ Die moeiliker vraagstuk is egter of verpligte MIV-toetse vir sekswerkers ingestel sal kan word. Hierdie vraagstuk vorm die kern van die bespreking en sal aan die hand van relevante gesag aandag geniet. Die posisie rakende verpligte MIV-toetsing van sekswerkers in Nevada (VSA) en Victoria (Australië), waar prostitusie reeds vir geruime periodes gedekriminaliseer is, volg daarna.

\section{SUID-AFRIKAANSE WETGEWING}

\section{Die Grondwet van die Republiek van Suid-Afrika, 1996}

Ingevolge artikel 12(2)(a)-(c) van die Grondwet van die Republiek van SuidAfrika, 1996 (hierna "die Grondwet") het elkeen die reg op liggaamlike en psigiese integriteit, waarby inbegrepe is:

"die reg om besluite oor voortplanting te neem; op sekerheid van en beheer oor die eie liggaam; en om nie sonder hul ingeligte toestemming aan mediese of wetenskaplike eksperimente onderwerp te word nie".

Verder het elkeen die reg op privaatheid ingevolge artikel $14,{ }^{10}$ waarby inbegrepe is die reg dat -

"hul persoon of woning nie deursoek word nie; hul eiendom nie deursoek word nie; daar nie op hul besittings beslag gelê word nie; of daar nie op die privaatheid van hul kommunikasies inbreuk gemaak word nie".

Ingevolge artikel 36 van die Grondwet kan hierdie regte slegs beperk word tot die mate waarin die beperking redelik en regverdigbaar is in 'n oop en demokratiese samelewing gebaseer op menswaardigheid, gelykheid en vryheid.

\section{Die Wet op Gelyke Indiensneming 55 van 1998}

Mediese toetsing van werknemers word tans deur die Wet op Gelyke Indiensneming ${ }^{11}$ gereguleer. Artikel 7 van die Wet plaas 'n algemene verbod op mediese toetsing, maar die verbod is nie absoluut nie. Artikel 7 lees soos volg:

"Medical testing:

7(1) Medical testing of an employee is prohibited, unless -

(a) legislation permits or requires the testing; or

(b) it is justifiable in the light of medical facts, employment conditions, social policy, the fair distribution of employee benefits or the inherent requirements of a job.

9 Botha Die Ontwikkeling van en die Regsproblematiek in verband met die Wettiging van Prostitusie in Suid-Afrika (LLD-proefskrif, Universiteit van die Vrystaat 2006) 179.

10 Art 14(a)-(d) van die Grondwet.

1155 van 1998. Hierdie wet is slegs in Engels beskikbaar. 
(2) Testing of an employee to determine that employee's HIV status is prohibited unless such testing is determined justifiable by the Labour Court in terms of section 50(4) of this Act."

Artikel $7(2)^{12}$ fokus spesifiek op die moontlikheid van verpligte MIVtoetsing. Die wetgewer stel dat MIV-toetsing verbode is, maar in sekere omstandighede soos uitgelê in Artikel 50(4), ${ }^{13}$ wel geldig mag wees.

Artikel 50(4) lees as volg:

"If the Labour Court declares that the medical testing of an employee as contemplated in section 7 is justifiable, the court may make any order that it considers appropriate in the circumstances, including imposing conditions relating to -

(a) the provision of counseling;

(b) the maintenance of confidentiality;

(c) the period during which the authorization for any testing applies; and

(d) the category or categories of jobs or employees in respect of which the authorization for testing applies."

Regter Landman merk egter tereg op dat, alhoewel artikel 7(2) bepaal dat die Arbeidshof ingevolge artikel 50(4) moet beslis of MIV-toetsing regverdigbaar is, artikel 50(4) slegs dui op die magte van die Arbeidshof indien daar bevind is dat die toetsing inderdaad regverdigbaar is. ${ }^{14}$

Hoe dit ook al sy, dit is duidelik dat indien 'n werkgewer die MIV-toetsing van sekswerkers (as wettige werknemers) in die toekoms sou wou afdwing, die aangeleentheid deur die Arbeidshof beslis sal moet word. Die Arbeidshof sal moet beslis of die toetsing regverdigbaar is en indien wel, ' $n$ bevel uitreik binne die raamwerk wat artikel 50(4) bied.

\section{TOEPASSING VAN DIE WETGEWING MET VERWYSING NA HOFSAKE}

Ter illustrasie van die Arbeidshof se toepassing van Art 50(4) geniet die volgende drie sake aandag:

\section{Joy Mining Machinery v NUMSA ${ }^{15}$}

In hierdie saak het die werkgewer aansoek gedoen ten einde MIV-toetse op sy werknemers te laat uitvoer. Nóg die unies nóg die werknemers was teen die MIV-toetsing gekant. Die hof het egter gestel dat, voor hy 'n werkgewer toestemming kan verleen om 'n MIV-toets voort te sit, die hof tevrede moet wees dat die toetsing regverdigbaar is. ${ }^{16}$

\footnotetext{
12 Wet op Gelyke Indiensneming 55 van 1998.

3 lbid.

14 Sien Irvin \& Johnson Ltd v Trawler \& Line Fishing Union 20034 BLLR 379 (LC) 384, par 16 soos aangehaal uit Joy Mining Machinery, a Division of Harnischfeger (SA) (Pty) Ltd $v$ National Union of Metalworkers of SA 200223 ILJ 391 (LC).

15 Supra.

16 Joy Mining Machinery v NUMSA supra 375 par 13.
} 
Regverdigbaarheid in die konteks van die Wet op Gelyke Indiensneming ${ }^{17}$ beteken dat die toets vir regverdigbaarheid die doel ${ }^{18}$ van die Wet moet bevorder. ${ }^{19}$ In die saak van PFG Building Glass (Pty) Ltd $v$ CEPPAWU ${ }^{20}$ is hierdie toets uitgebrei en die bespreking daarvan volg in paragraaf 33 .

Soos reeds genome, bied Artikel 7(2) van die Wet verder geen riglyne wat betref wanneer die toetsing inderdaad billik sal wees nie en word daar aan die hand gedoen dat die faktore wat teenwoordig moet wees of oorweging moet geniet by die bepaling van regverdigbaarheid van algemene mediese toesting soos in artikel 7(1)(b) van die Wet uiteengesit, ook gebruik kan word om te bepaal of MIV-toetsing regverdigbaar is. ${ }^{21}$ Dit sluit onder andere in dat die toets regverdigbaar moet wees in die lig van mediese feite, werksomstandighede, sosiale beleid, billike verspreiding van werknemersvoordele of inherente vereiste vir die werk. ${ }^{22}$

Die hof het na oorweging van bogenoemde en inaggenome die feit dat die werknemers die toetsing vrywillig wou ondergaan, met konfidensialiteit gewaarborg, 'n bevel toegestaan ingevolge waarvan magtiging tot toetsing verleen is. ${ }^{23}$

\section{Irvin \& Johnson v Trawler Line Fishing Union ${ }^{24}$}

Die applikant wat meer as 1100 werknemers in diens gehad het, wou reëlings tref vir die vrywillige en anonieme MIV-toetsing van sy werknemers. Meer spesifiek het hy aansoek gedoen om 'n bevel dat die toetsing nie onderworpe is aan goedkeuring ingevolge artikel 7(2) van die Wet deur die

\footnotetext{
55 van 1998.

18 Die doel van die Wet soos uiteengesit in die voorwoord, lees as volg:

"Recognising -

that as a result of apartheid and other discriminatory laws and practices, there are disparities in employment, occupation and income within the national labour market; and

that those disparities create such pronounced disadvantages for certain categories of people that they cannot be redressed simply by repealing discriminatory laws.

Therefore in order to -

promote the constitutional right of equality and the exercise of true democracy; eliminate unfair discrimination in employment;

ensure the implementation of employment equity to redress the effects of discrimination;

achieve a diverse workforce broadly representative of our people;

promote economic development and efficiency in the workforce; and

give effect to the obligations of the Republic as a member of the International Labour Organisation."

19 Joy Mining Machinery v NUMSA supra 375 Editors Summary asook par 15. Sien ook Artike 2(a) en (b) van die Wet op Gelyke Indiensneming 55 van 1998: Die doel van die Wet is om gelykheid in die werkplek te bevorder. 
Arbeidshof nie; alternatiewelik, dat die Arbeidshof die toetsing as regverdigbaar (in terme van artikel 50(4) van die Wet) sal verklaar. ${ }^{25}$

In die Irvin \& Johnson $v$ Trawler Line Fishing Union-saak ${ }^{26}$ is daar gestel dat waar werknemers toestemming gee tot MIV-toetsing, die aangeleentheid nie meer van goedkeuring deur die Arbeidshof afhanklik is nie. ${ }^{27}$ Derhalwe sal dit ook onnodig wees vir die Arbeidshof om te bepaal of die MIV-toetsing regverdigbaar is. ${ }^{28}$

Hierdie saak kan as 'n deurbraak geag word in die lig daarvan dat, waar werknemers vrywillig tot toetsing instem, die Arbeidshof voortaan nie meer genader hoef te word nie. ${ }^{29}$

\section{PFG Building Glass Ltd v CEPPAW ${ }^{30}$}

In die PFG Building Glass (Pty) Ltd-saak ${ }^{31}$ het die werkgewer MIV-toetse op sy werknemers laat doen, sonder vooraf toestemming deur die hof en het aangevoer dat sodanige toestemming onnodig was aangesien die werknemers almal daartoe toegestem het. Die hof het tot die bevinding gekom dat dit dwaas sou wees om die $\mathrm{Wet}^{32}$ so te interpreteer dat goedkeuring deur die Arbeidshof steeds ' $n$ vereiste is, waar die werknemers tot die toetsing instem. ${ }^{33}$

Wat hierdie saak verder van belang maak, is die stelling deur die hof dat in die geval van mediese toetse, die data relevant moet wees, daar op vertroulikheid ooreengekom moet word en onderwerping aan die toets, vrywillig moet wees. ${ }^{34}$ Die resultate moet in alle gevalle vertroulik gehou word met enkele uitsonderings. ${ }^{35}$ 'n Uitsonderlike geval is waar die werkgewer wil weet wat die MIV-status van sekere werknemers is omrede 'n MIV-vrye-status ' $n$ inherente vereistes van die werk is. ${ }^{36}$ Die hof stel egter dat die onus om MIV-vrye-status as inherente vereiste te bewys nie maklik haalbaar is nie. ${ }^{37}$

Regter Pillay ${ }^{38}$ stel verder dat, waar die werkgewer nie toestemming vanaf die werknemers sou verkry om MIV-toetsing te doen nie, of wel toestemming verkry, maar die werknemers nie behoorlik ingelig was nie, die aangeleentheid na die Arbeidshof moet gaan. Die Arbeidshof sal dan die

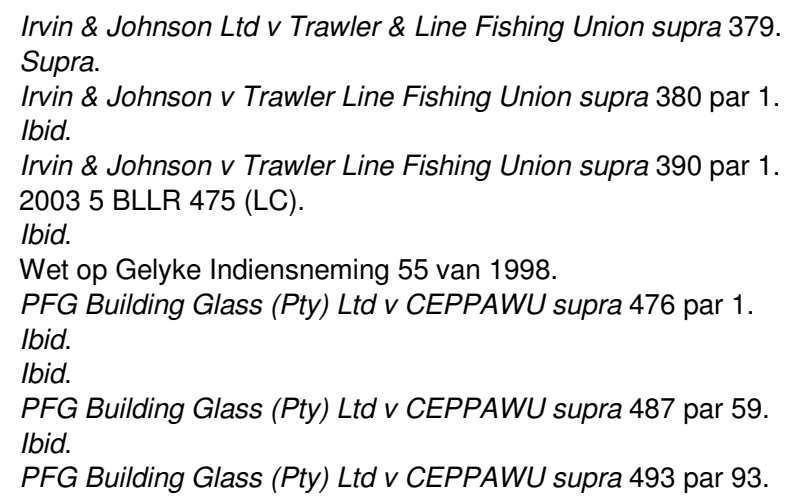


regverdigbaarheid van die toetsing moet bepaal. ${ }^{39}$ Volgens die hof word dit eenvoudig gedoen deur die toets vir regverdigbaarheid van die beperking, wat in vier opgedeel kan word, naamlik:

\section{- Die aard van die reg en die belang van die beperking}

Die hof het gestel dat met betrekking tot artikel 12 van die Grondwet, ${ }^{40}$ die belang van die doel van die beperking sal afhang van die rede waarvoor die toets verkry word. ${ }^{41}$ Vir watter rede ook al die toets verkry word, mag sy doel of effek nie onbillik diskrimineer nie. ${ }^{42}$

\section{- Die aard en omvang van die beperking}

Om die aard en omvang van die beperking te bepaal moet die hof na die hele proses van die toetsing kyk, vanaf die opvoedkundige en informasieverspreiding, tot die metode van toetsing, raadgewing voor-en-natoetsing, observasie van konfidensialiteit, mediese etiek en ander regte van die werknemer. Volgens Regter Pillay ${ }^{43}$ is die speekseltoets, soos gevolg in die Joy Mining Machinery-saak, ${ }^{44}$ die minste inbreukmakende metode van toetsing. Bloedtoetse is aanvaar in die Irvin \& Johnson Ltdsaak. $^{45}$ Die toets moet egter nóg die werknemer tot ander gesondheidsrisiko's blootstel, nóg moet dit die gevolg hê dat daar inbreuk gemaak word op ander fundamentele regte van die werknemer. ${ }^{46}$

\section{- Die verhouding tussen die doel en die beperking}

Deur objektief te kyk moet daar 'n direkte en rasionele verband tussen die MIV-toetsing en die doel daarvan wees. ${ }^{47}$ Indien die doel van die toetsing is om te bepaal of die werknemer MIV-positief is, sal die Arbeidshof meer behoudsaam moet wees as gevolg van die feit dat die potensiaal van onbillike diskriminasie, inbreukmaking op privaatheid, onbillike arbeidspraktyk en skending van fundamentele regte, toeneem. ${ }^{48}$ As die doel van die toetsing onverwant is tot die bestuur van die onderneming, sal dit nie regverdigbaar wees nie, aangesien dit inter alia 'n inbreukmaking van privaatheid sal wees. ${ }^{49}$

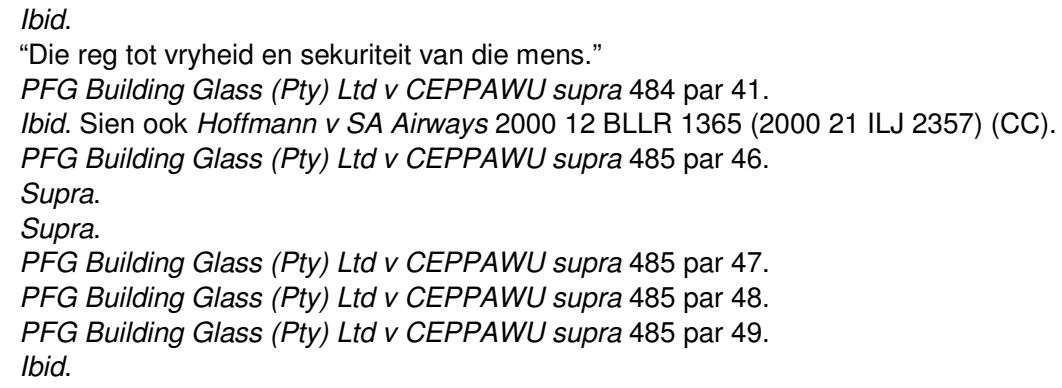




\section{- Kon beperking op 'n minder inbreukmakende wyse geskied? ${ }^{50}$}

Geen minder inbreukmakende toets, anders as die speeksel of bloedtoets, is in dié saak of enige ander saak al aangevoer nie. ${ }^{51}$

Uit bogenoemde regspraak kan afgelei word dat, indien sekswerkers (as wettige werknemers) na dekriminalisering sou instem om MIV-toetsing te ondergaan, dit sal kan plaasvind sonder om die Arbeidshof te nader. Waar sekswerkers egter nie tot die toetsing sou toestem nie, sal die Arbeidshof genader moet word om die regverdigbaarheid van die toetsing te bepaal. Indien die werkgewer verder die resultate van die MIV-toetsing sou wou openbaar, sal die werkgewer die onus van inherente werksvereiste moet weerlê. Of die inbreukmaking regverdigbaar is, sal aan die hand van artikel 36 van die Grondwet bepaal moet word.

Die hof noem verder pertinent in die PFG Building Glass-saak ${ }^{52}$ dat die omstandighede waaronder die Arbeidshof die onvrywillige MIV-toetsing van werknemers sal toelaat, onseker is. Daar is nog geen saak van dié aard na die Arbeidshof verwys nie en dit is nie moontlik om 'n lys van omstandighede saam te stel wanneer verpligte toetsing wel toelaatbaar sal wees nie. Hierdie grondwetlike aangeleentheid behoort stelselmatig, saak vir saak, te ontwikkel. ${ }^{53}$

\section{DIE PROBLEEM RONDOM SEKSWERKERS WAT ONAFHANKLIKE KONTRAKTEURS IS}

Volgens die Wet op Gelyke Indiensneming ${ }^{54}$ word werknemers soos volg gedefinieer:

"any person other than an independent contractor who -

(a) works for another person or for the State and who receives, or is entitled to receive, any remuneration; and

(b) in any manner assists in carrying on or conducting the business of an employer.

\footnotetext{
PFG Building Glass (Pty) Ltd v CEPPAWU supra 483-486 par 33-59.

PFG Building Glass (Pty) Ltd v CEPPAWU supra 485 par 50.

Supra.

PFG Building Glass (Pty) Ltd v CEPPAWU supra 494-495 par 103.

55 van 1998.

55 Sien ook Art 200 A van die Wet op Arbeidsverhoudinge 66 van 1995 wat die vermoede dat 'n persoon 'n werknemer is, soos volg uiteensit:

"(1) Totdat die teendeel bewys is, word daar vermoed dat 'n persoon wat werk vir, of dienste lewer aan, enige ander persoon, ongeag die vorm van die kontrak, 'n werknemer is, indien een of meer van die volgende faktore aanwesig is:

(a) Die wyse waarop die persoon werk, is onderhewig aan die beheer of leiding van 'n ander persoon;

(b) die persoon se werksure is onderhewig aan die beheer of leiding van 'n ander persoon;

(c) in die geval van 'n persoon wat vir 'n organisasie werk, maak die persoon deel van daardie organisasie uit;
} 
Dus sal die bepalinge van die Wet op Gelyke Indiensneming ${ }^{56}$ soos hierbo bespreek, slegs op sekswerkers van toepassing kan wees, indien hulle as werknemers kwalifiseer. Die onafhanklike sekswerkers val nie binne die raamwerk van die Wet nie en 'n bevel van verpligte MIV-toetsing sal dus nie ingevolge artikel $50(4)^{57}$ ten opsigte van hul gemaak kan word nie.

Daar sal dus na wetgewing gekyk moet word wat sekswerkers sal verplig om slegs as werknemers op te tree, en dat onafhanklike kontrakteurs, onwettig sal wees. ${ }^{58}$

\section{DIE POSISIE IN NEVADA (VERENIGDE STATE VAN AMERIKA)}

\section{$51 \quad$ Inleiding}

Prostitusie in Nevada is in 1971 ingevolge die Nevada Revised Statutes (NRS) 224.245. gedekriminaliseer en word vandag steeds gereguleer. ${ }^{59}$ In 1978 het die Hoë Hof beslis dat, as gevolg van die aanvaarding van die gemeenskap, huise van prostitusie (bordele) nie langer as 'n openbare hindernis geag kan word nie. ${ }^{60}$ In 1980 is finaal beslis dat streke met 'n bevolking van kleiner as 400000 , bordele kan lisensieer en reguleer. ${ }^{61}$ In 1987 is NRS 201.354. ingestel en dit lees soos volg: ${ }^{62}$

"Engaging in prostitution or solicitation for prostitution: Penalty; exception.

1. It is unlawful for any person to engage in prostitution or solicitation therefor, except in a licensed house of prostitution.

2. Any person who violates subsection 1 is guilty of a misdemeanor."63

\section{5 van 1988.}

57 Wet 55 van 1988.

58 Sien ook Botha en Oosthuizen "Diskriminalisering nie die Enigste Struikelblok in Sekswerkers se Stryd om Arbeidsregte nie" 2010 31(1) Obiter 112 in hierdie verband: "Die arbeidsregte, soos in die meeste arbeidswetgewing uiteengesit, is egter slegs op werknemers en nie ook op onafhanklike kontrakteurs nie, van toepassing. Sou sekswerkers dus na die dekriminalisering van die seksbedryf as onafhanklike kontrakteurs hanteer word, sal dekriminalisering op die gebied van arbeidsreg, 'n waardelose triomftog wees."

59 Davis "Prostitution" 2006 VII Georgetown Journal of Gender and the Law 840.

60 Brents en Hausbeck "State-sanctioned Sex: Negotiating Formal and Informal Regulatory Practices in Nevada Brothels" 2001 44(3) Sociological Perspectives 313.

61 Ibid. Sien ook Davis 2006 VII Georgetown Journal of Gender and the Law 840.

62 Brents en Hausbeck 2001 44(3) Sociological Perspectives 313; en sien ook Nevada Revised Statutes 201.356.

63 Sien NRS 193.150. 
Volgens Brents ${ }^{64}$ is NRS 201.354. ingestel om prostitusie wat nie in 'n bordeel plaasvind nie, onwettig te verklaar. Die straf vir die oortreding van NRS 201.354. is geleë in NRS 193.150. en lees soos volg:

"Punishment of misdemeanors.

1. Every person convicted of a misdemeanor shall be punished by imprisonment in the county jail for not more than 6 months, or by a fine of not more than $\$ 1,000$, or by both fine and imprisonment, unless the statute in force at the time of commission of such misdemeanor prescribed a different penalty.

2. In lieu of all or a part of the punishment which may be imposed pursuant to subsection 1 , the convicted person may be sentenced to perform a fixed period of community service pursuant to the conditions prescribed in NRS 176.087.

Dus om as 'n sekswerker te werk is wettig, maar slegs indien dit plaasvind in 'n gelisensieerde bordeel. Indien die bepaling oortree word, sal die sekswerker skuldig wees aan wangedrag wat strafbaar is met tronkstraf wat nie 6 maande mag oorskry nie en/of 'n boete van $\$ 1,000$.

\section{Verpligte MIV-toetsing}

In 1985 het die Nevada Administrative Code (NAC) voorstelle neergelê wat mediese-toetsing van sekswerkers reguleer en in 1986 is MIVtoetsing ook hierby bygevoeg. ${ }^{66}$ NAC $441 \mathrm{~A} .800$. handel oor die toetsing van sekswerkers asook die verbod op indiensneming van sekere persone as sekswerkers. ${ }^{67}$ Volgens NAC 441.A800.: subartikel 1, moet ' $n$ persoon wat aansoek doen as 'n sekswerker by 'n gelisensieerde bordeel, mediese toetsing ondergaan om vas te stel of die persoon nie enige seksueel-oordraagbare siektes het nie. ${ }^{68}$

NAC 441A.800.: subartikel 2, bepaal dat 'n persoon nie as 'n sekswerker indiens geneem mag word, voordat die toetse soos in subartikel 1 versoek, toon dat die persoon inderdaad geen seksueeloordraagbare siektes (insluitende MIV) het nie. ${ }^{69}$

64 Brents en Hausbeck 2001 44(3) Sociological Perspectives 313.

65 Sien NRS 176.087.

66 Brents en Hausbeck 2001 44(3) Sociological Perspectives 313.

67 Nevada Administrative Code 441A.800.

68 NAC 441.A800. subartikel 1:

"A person seeking employment as a prostitute in a licensed house of prostitution shall submit to the State Hygienic Laboratory in the Division or a medical laboratory licensed pursuant to chapter 652 of NRS and certified by the Health Care Financing Administration of the United States Department of Health and Human Services:

(a) A sample of blood for a test to confirm the presence or absence of human immunodeficiency virus infection (HIV) and syphilis; and

(b) A cervical specimen for a test to confirm the presence or absence of gonorrhea and Chlamydia trachomatis by culture or antigen detection or DNA probe."

69 NAC 441A.800. subartikel 2:

"A person must not be employed as a prostitute in a licensed house of prostitution until the State Hygienic Laboratory in the Division or a medical laboratory licensed pursuant to chapter 652 of NRS and certified by the Health Care Financing Administration of the United States Department of Health and Human Services has reported that the tests 
Die Nevada Administrative Code bepaal in NAC 441A.800. subartikel $3(a)$, dat die sekswerkers by 'n gelisensieerde bordeel een keer per maand 'n bloedtoets moet ondergaan om vir MIV sowel as vir sifilis te toets. ${ }^{70} \mathrm{NAC} 441 \mathrm{~A} .800$. subartikel 3(b) bepaal verder dat sekswerkers ook een keer per week 'n servikale monster moet inlewer vir toetsing om vas te stel of die sekswerker gonorree of Chlamydia trachomatis het.

Sou die uitslag aantoon dat die persoon MIV, gonorree of Chlamydia trachomatis het, sal die sekswerker onmiddellik ontslaan word as sekswerker in 'n gelisensieerde bordeel. ${ }^{72}$

Uit die bespreking van NAC 441A.800. soos hierbo vermeld, kan gesien word dat daar streng bepalings bestaan om die verspreiding van MIV sowel as ander seksueel-oordraagbare siektes te voorkom. Verdere voorsorgmaatreëls word getref deur NAC 441A.805. ingevolge waarvan sekswerkers 'n lateks-voorbehoedmiddel (kondoom) moet gebruik tydens die verrigting van seksuele dienste. ${ }^{73}$

Die sukses van bogenoemde bepalings blyk duidelik uit die feit dat vanaf die instelling van verpligte toetsing in 1986, daar nog geen sekswerker in 'n gelisensieerde bordeel MIV-positief getoets het nie. ${ }^{74}$ Hierdie rekord kan nie deur die algemene populasie bereik word nie en dit maak in werklikheid uit 'n gesondheidsoogpunt, seksuele omgang met 'n sekswerker van Nevada in

required pursuant to subsection 1 do not show the presence of infectious syphilis, gonorrhea, Chlamydia trachomatis or infection with the human immunodeficiency virus (HIV)."

70 NAC 441A.800. subartikel 3 :

"A person employed as a prostitute in a licensed house of prostitution shall submit to the State Hygienic Laboratory in the Division or a medical laboratory licensed pursuant to chapter 652 of NRS and certified by the Health Care Financing Administration of the United States Department of Health and Human Services:

(a) Once each month, a sample of blood, identified by the name of the prostitute as it appears on her local work permit card, for a test to confirm the presence or absence of:

(1) Infection with the human immunodeficiency virus (HIV); and

(2) Syphilis."

71 NAC 441A.800. subartikel 3 (b):

"Once each week, a cervical specimen, identified by the name of the prostitute as it appears on her local work permit card, for a test to confirm the presence or absence of gonorrhea and Chlamydia trachomatis by culture or antigen detection or DNA probe."

72 NAC 441A.800. Subartikel 4:

"If a test required pursuant to this section shows the presence of infectious syphilis, gonorrhea, chlamydia trachomatis or infection with the human immunodeficiency virus (HIV), the person shall immediately cease and desist from employment as a prostitute in a licensed house of prostitution."

73 NAC 441A.805:

"A person employed as a prostitute in a licensed house of prostitution shall require each patron to wear and use a latex prophylactic while engaging in sexual intercourse, oralgenital contact or any touching of the sexual organs or other intimate parts of a person."

74 Davis 2006 VII Georgetown Journal of Gender and the Law 841; en sien ook Brents en Hausbeck 2001 44(3) Sociological Perspectives 314. 
sommige gevalle veiliger as seksuele omgang in die huwelik en baie veiliger as die tipiese "one-night-stand". ${ }^{75}$

Daar is egter wel 'n probleem met betrekking tot onwettige prostitusie, dit wil sê sekswerkers wat nie aan 'n gelisensieerde bordeel behoort nie. 'n Streng maatreël geld egter hier met betrekking tot sekswerkers, hetsy in 'n gelisensieerde bordeel of andersins, wat MIV-positief is. ${ }^{76}$ Die maatreël word vervat in NRS 201.358. en stel dat 'n MIV-positiewe sekswerker wat voortgaan om seksuele dade as 'n sekswerker te verrig skuldig aan 'n klas $B$-oortreding is en gestraf kan word deur tronkstraf van ' $n$ minimum van twee jaar, tot 'n maksimum van tien jaar en/of 'n boete van $\$ 10,000 .^{77}$

\section{DIE POSISIE IN VICTORIA (AUSTRALIË)}

\section{Inleiding}

Prostitusie word al sedert 1986 as wettig in Victoria beskou. ${ }^{78}$ Die Prostitution Regulation Act van 1986 het sekere vorme van prostitusie gewettig en is later deur die Prostitution Control Act van 1994 vervang. ${ }^{79}$ Die belangrikste voorskrifte met betrekking tot prostitusie, vir hierdie studie van belang, is die Prostitution Control Act van 1994 en die Health (Infectious Diseases) Regulations van 2001. 'n Kort bespreking van elk van laasgenoemdes, met spesifieke fokus op regulasies ten opsigte van seksueel-oordraagbare siektes (insluitende MIV), volg hieronder.

\section{Prostitution Control Act van 1994}

In afdeling 2 van die Prostitution Control Act van 1994 is daar twee artikels wat veral van belang is, naamlik artikel 19 en artikel 20. Beide artikels handel oor die feit dat sekswerkers wat 'n seksueel-oordraagbare siekte ${ }^{80}$ het, nie as 'n sekswerker vir die tydperk waarmee hulle met die siekte geïnfekteer is, mag werk nie. ${ }^{81}$

75 Leggett "The Least Formal Sector: Women in Sex Work" 199813 Crime and Conflict 21-24; en sien ook Botha (LLD-proefskrif, Universiteit van die Vrystaat 2006) 190.

76 Bingham "Nevada Sex Trade: A Gamble for the Workers" 199810 Yale Journal of Law and Feminism 89.

77 Sien BELINDA GLEGOLA, Appellant, v. THE STATE OF NEVADA, No. 23050, 1994 en sien verder Bingham 199810 Yale Journal of Law and Feminism 89; asook NRS 201.358. subartikel 1: "A person who: (a) Violates NRS 201.354.; or (b) Works as a prostitute in a licensed house of prostitution, after testing positive in a test approved by the state board of health for exposure to the human immune deficiency virus and receiving notice of that fact is guilty of a category $B$ felony and shall be punished by imprisonment in the state prison for a minimum term of not less than 2 years and a maximum term of not more than 10 years, or by a fine of not more than $\$ 10,000$, or by both fine and imprisonment."

78 Botha (LLD-proefskrif, Universiteit van die Vrystaat 2006) 328.

79 lbid.

80 Dit is veral van belang om daarop te let dat artikel 6 van die Prostitution Control Regulations van 2006 verwys na artikel 3 van die Health Act van 1958, ingevolge waarvan MIV ook as 'n seksueel-oordraagbare siekte beskou word.

81 Prostitution Control Act van 1994. 
Artikel 19(1) plaas 'n verpligting op die sekswerker se verskaffer, of die bestuurder van die bordeel, om nie 'n sekswerker toe te laat om in 'n bordeel te werk gedurende die tydperk wat hy/sy weet die sekswerker met 'n seksueel-oordraagbare siekte geïnfekteer is nie. ${ }^{82}$ Die persoon waarop die verpligting in artikel 19(1) geplaas word, word vermoed kennis van die seksueel-oordraagbare siekte te gedra het. ${ }^{83}$

Hierdie persoon kan die vermoede weerlê deur te bewys dat hy/s tydens die pleeg van die misdryf:

“(1) redelik geglo het dat die sekswerker gereelde skrop ('swab') toetsing ondergaan het (ten minste een keer per maand), met die doel om vas te stel of hy/sy 'n seksueel-oordraagbare siekte het:

(2) redelik geglo het dat die sekswerker nie geïnfekteer was met 'n seksueeloordraagbare siekte nie". ${ }^{4}$

Die straf vir die oortreding van artikel 19 is gelyk aan 50 "penalty units". ${ }^{85}$ Wat presies gesien word as 'n "penalty unit" word nie in die wet omskryf nie, maar blyk gekoppel te word aan 'n spesifieke bedrag geld, vir 'n spesifieke finansiële periode. ${ }^{86}$ ' $n$ "Penalty unit" is tans gelykstaande aan $\$ 116.82$, en geld vir die finansiële periode vanaf 1 Julie 2009 tot 30 Junie $2010 .{ }^{87}$

Artikel 20(1) van die Prostitution Control Act van 1994 plaas weer 'n beperking op die sekswerker self om nie tydens die periode waarin hy/sy geïnfekteer is met 'n seksueel-oordraagbare siekte, as 'n sekswerker te werk nie. ${ }^{88}$ Artikel 20(2) skep die vermoede dat 'n sekswerker kennis gedra het van die seksueel-oordraagbare siekte, ten tyde van die pleeg van die misdryf. ${ }^{89}$ Dieselfde twee gronde waarop die vermoede in artikel 19 weerlê

82 "Section 19(1): A person who -

(a) is a prostitution service provider; or

(b) manages a brothel or an escort agency or any other business that provides prostitution services - must not permit a prostitute to work (whether under a contract of service or a contract for services) in a brothel or for the escort agency or other business during any period in which he or she knows that the prostitute is infected with a sexually transmitted disease. Penalty: 50 penalty units."

83 "Section 19(2): If it is proved to a court that a person referred to in subsection (1) permitted a prostitute to work as mentioned in that subsection during a period in which the prostitute was infected with a sexually transmitted disease, that person must be presumed to have known that the prostitute was so infected unless that person proves that at the time the offence is alleged to have been committed that person believed on reasonable grounds -

(a) that the prostitute had been undergoing -

(ii) regular swab tests, on at least a monthly basis, for the purpose of determining whether he or she was infected with any other sexually transmitted disease; and (b) that the prostitute was not infected with a sexually transmitted disease." Artikel 19(2)(a) en (b) van Prostitution Control Act van 1994.

85 Artikel 19 van die Prostitution Control Act van 1994.

86 http://www.legalaid.vic.gov.au/1700.htm (nageslaan 2010-06-11).

87 lbid.

88 "Section 20(1): A person must not work as a prostitute during any period in which he or she knows that he or she is infected with a sexually transmitted disease. Penalty: 20 penalty units."

89 "Section 20(2): If it is proved to a court that a person worked as a prostitute during a period in which he or she was infected with a sexually transmitted disease, he or she 
kan word, geld by artikel 20(2). ${ }^{90}$ In artikel 20(2)(a)(i) ${ }^{91}$ word daar egter 'n derde grond bygevoeg wat stel dat die vermoede ook weerlê kan word indien die sekswerker kan bewys dat hy/sy gereeld bloedtoetse ondergaan het, ten minste op ' $n$ kwartaallikse basis, met betrekking tot die vastelling of hy/sy MIV-positief is. Die straf vir die oortreding van artikel $20^{92}$ is slegs 20 "penalty units" ${ }^{\text {"93 }}$ wat ligter is as die straf vir die oortreding van artikel 19, wat op die sekswerker se verskaffer of die bestuurder van die bordeel, van toepassing is.

\section{The Health (Infectious Diseases) Regulations van 2001}

Afdeling ses van The Health (Infectious Diseases) Regulations van 2001, bespreek aangeleenthede met betrekking tot bordele. In artikel 27 van The Health (Infectious Diseases) Regulations van 2001, word voorsiening gemaak dat die eienaar (of soos in die wet genoem "proprietor"94) van die gelisensieerde bordeel, die sekswerkers met gratis kondome moet verskaf. ${ }^{95}$ Die eienaar word in artikel 28 van die Wet ook verplig om te verseker dat die sekswerker en die kliënt gebruik maak van ' $n$ kondoom in die uitvoering van seksuele dade, onder andere anale, orale of vaginale penetrasie. ${ }^{96}$ Ingevolge artikel $29^{97}$ mag die eienaar ook nie 'n sekswerker verplig om seksuele omgang met 'n kliënt te hê nadat hy/sy geweier het nie. Die Wet noem egter slegs twee gronde van weiering, naamlik 1) die sekswerker vermoed dat die kliënt 'n seksueel-oordraagbare siekte het, 2) die kliënt weier om 'n kondoom te gebruik. ${ }^{98}$

must be presumed to have known that he or she was so infected unless he or she proves that at the time the offence is alleged to have been committed -

(a) that he or she had been undergoing -

(i) regular blood tests, on at least a quarterly basis for HIV and each other sexually transmitted disease for which blood tests are appropriate; and

(ii) regular swab tests, on at least a monthly basis, for the purpose of determining whether he or she was infected with any other sexually transmitted disease; and

(b) he or she believed on reasonable grounds that he or she was not infected with a sexually transmitted disease."

Artikel 20(2)(a)(ii) en (b) van die Prostitution Control Act van 1994.

Prostitution Control Act van 1994.

Prostitution Control Act van 1994.

Artikel 20(1) van die Prostitution Control Act van 1994.

94 "Section 26: proprietor means the proprietor of the business of operating a brothel or the person in charge of a brothel."

95 "Section 27: Provision and storage of condoms

(1) A proprietor must provide, in the brothel, a free supply of -

(a) condoms; and

(b) water based lubricant -

which is readily accessible by prostitutes and clients."

96 "Section 28(1): A proprietor must take reasonable steps to ensure that a client and a prostitute use condoms in any encounter in a brothel between a client and a prostitute which involves vaginal, oral or anal penetration whether by means of a penis or other part of the body or by a device or object."

97 "The Health (Infectious Diseases) Regulations van 2001."

98 "Section 29: A proprietor must not require a prostitute to provide a service to a client if the prostitute has refused to provide the service because - 
Die sukses van Australië se benadering spreek duidelik uit die feit dat MIV onder sekswerkers minder as $1 \%$ is en dit minder is as die algemene voorkoms van MIV onder die res van die algehele bevolking. ${ }^{99}$

\section{SAMEVATTING EN VOORSTELLE}

Dit is 'n onbetwiste feit dat die dekriminalisering van die seksbedryf ' $n$ rimpelingeffek op vele ander terreine van die samelewing, insluitende MIVverspreiding, tot gevolg kan hê. Suid-Afrika is dus genoop om vroegtydig voorsorg te tref teen MIV-verspreiding, sou dekriminalisering inderdaad plaasvind.

Met die fokus op sekswerkers as potensiële verspreiders van MIV in die lig van hul daaglikse werksaamhede, onstaan die vraag of verpligte MIVtoetse op hulle afgedwing sal kan word, sou dekriminalisering plaasvind. Artikel 7(2) van die Wet op Gelyke Indiensneming ${ }^{100}$ reguleer tans die moontlikheid van MIV-toetsing in die werkplek en stel dat MIV-toetsing in die algemeen verbode is, maar in sekere omstandighede deur die Arbeidshof gemagtig kan word. $\mathrm{Na}$ aanleiding van die bespreking van Suid-Afrikaanse hofgesag op die gebied, kan afgelei word dat, indien sekswerkers (as wettige werknemers) na dekriminalisering sou instem om MIV-toetsing te ondergaan, dit sal kan plaasvind sonder om die Arbeidshof te nader. ${ }^{101}$ Waar sekswerkers egter nie tot die toetsing sou toestem nie, sal die Arbeidshof genader moet word om die billikheid van die toetsing te bepaal. Die hof noem verder pertinent in die PFG Building Glass-saak ${ }^{102}$ dat die omstandighede waaronder die Arbeidshof die onvrywillige MIV-toetsing van werknemers sal toelaat, onseker is. Daar is nog geen saak van dié aard na die Arbeidshof verwys nie en dit is nie moontlik om 'n lys van omstandighede saam te stel wanneer verpligte MIV-toetsing wel toelaatbaar sal wees nie.

Daar moet ook in gedagte gehou word dat die Wet op Gelyke Indiensneming ${ }^{103}$ slegs van toepassing is op persone wat as werknemers (uitsluitende onafhanklike kontrakteurs) onder die Wet kwalifiseer. Dienooreenkomstig sal slegs sekswerkers wat as werknemers aan 'n bordeel verbonde is, ingevolge die bestaande wetgewing moontlik aan verpligte MIV-toetsing onderwerp kan word.

Uit die vergelykende studie blyk die voorbeeld wat in Nevada gevolg word as moontlike oplossing vir Suid-Afrika te dien. Sekswerkers mag hier slegs as deel van bordele diens lewer en word aan maandelikse verpligte MIVtoetsing onderwerp. ${ }^{104}$ MIV-positiewe sekswerkers wat voortgaan met diens

(a) the prostitute suspects that the client is infected with an infectious disease; or

(b) the client has refused to use a condom."

99 mAy-welby "The Importance of Facing HIV/AIDS with Scrupulous Honesty" 2004 5(1) InterAsia Cultural Studies 151.

10055 van 1998.

101 Irvin \& Johnson v Trawler Line Fishing Union supra 390 par 1.

102 Supra.

10355 van 1998.

104 Sien NRS 201.354.; NRS 193.150.; asook NAC 441A.800. 
is onderworpe aan strafmaatreëls. Hierdie maatreël word vervat in NRS 201.358. en stel dat ' $n$ sekswerker wat seksuele dienste verrig, wetende dat sy MIV-postitief is, haarself skuldig maak aan 'n klas B oortreding en met gevangenisstraf van 'n minimum van twee jaar tot 'n maksimum van tien jaar en/of 'n boete van $\$ 10000$ gestraf kan word. ${ }^{105}$

In Victoria is sekwerkers nie ingevolge wetgewing verplig om MIV-toetsing te ondergaan nie, maar pleeg hul 'n misdryf indien hul sou voortgaan met seksuele dienste, wetende dat hul geïnfekteer is met 'n seksueeloordraagbare siekte. ${ }^{106}$ Daar bestaan verder 'n vermoede dat die sekswerker bewus was van die seksueel-oordraagbare siekte en hierdie vermoede kan slegs weerlê word deur middel van bewys daarvan dat gereelde mediesetoetsing deur die sekswerker ondergaan is. ${ }^{107}$

Die sukses van die benaderings soos gevolg in Nevada en Victoria blyk duidelik uit die lae MIV-syfers wat deur die seksbedryf in die onderskeie lande gehandhaaf word. ${ }^{108}$

Voordat dekriminalisering plaasvind, behoort Suid-Afrika ernstige oorweging te skenk aan weldeurdagte wetgewing wat die seksbedryf sal reguleer. Die voordele verbonde daaraan om sekswerkers van meet af aan te verplig om slegs in bordele werksaam te wees, onderworpe aan verpligte MIV-toetse, spreek vanself. Indien die grondwetlikheid van verpligte MIVtoetsing in ons land egter geweeg en te lig bevind sal word, kan die benadering van Victoria gevolg word. Ingevolge hierdie benadering sal daar nie direk op die sekswerker se menseregte inbreuk gemaak word soos in die geval van verpligte MIV-toetsing nie, maar sy/hy eerder op 'n indirekte wyse verplig word om self die toetsing op ' $n$ gereelde basis te ondergaan om te verseker dat die vermoede (van kennis van MIV-status) weerlê sal kan word, sou strafregtelike vervolging plaasvind.

105 Sien BELINDA GLEGOLA, Appellant, v. THE STATE OF NEVADA, No. 23050, 1994. Sien verder Bingham 199810 Yale Journal of Law and Feminism 89 asook NRS 201.358. subartikel 1: "A person who: (a) Violates NRS 201.354.; or (b) Works as a prostitute in a licensed house of prostitution, after testing positive in a test approved by the state board of health for exposure to the human immune deficiency virus and receiving notice of that fact is guilty of a category B felony and shall be punished by imprisonment in the state prison for a minimum term of not less than 2 years and a maximum term of not more than 10 years, or by a fine of not more than $\$ 10000$, or by both fine and imprisonment."

106 Prostitution Control Act van 1994: Artikel 20(1).

107 Prostitution Control Act van 1994: Artikel 20(2).

108 Sien Davis 2006 VII Georgetown Journal of Gender and the Law 841; Brents en Hausbeck 2001 44(3) Sociological Perspectives 314; en sien verder mAy-welby 2004 5(1) Inter-Asia Cultural Studies 151. 